Original Article

\title{
Identification by molecular techniques of halophilic bacteria producing important enzymes from pristine area in Campeche, Mexico
}

\author{
Identificação por técnicas moleculares de bactérias halofílicas que produzem enzimas \\ importantes em área intocada de Campeche, México
}

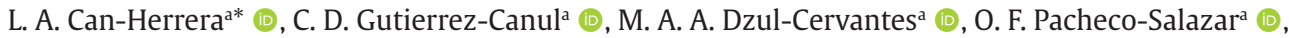 \\ J. D. Chi-Cortez ${ }^{\mathrm{b}}$ (1) and L. Saenz Carbonell ${ }^{\mathrm{b}}$ (1) \\ aInstituto Tecnológico Superior de Calkiní en el Estado de Campeche - ITESCAM, Calkiní, Campeche, México \\ ${ }^{\text {b} C e n t r o ~ d e ~ I n v e s t i g a c i o ́ n ~ C i e n t i ́ f i c a ~ d e ~ Y u c a t a ́ n ~-~ C I C Y, ~ U n i d a d ~ d e ~ C i e n c i a s ~ B i o l o ́ g i c a s, ~ M e ́ r i d a, ~ Y u c a t a ́ n, ~ M e ́ x i c o ~}$
}

\begin{abstract}
Isla Arena is located in the coordinate $20^{\circ} 70^{\prime} \mathrm{N}-90^{\circ} 45^{\prime} \mathrm{W}$, from Campeche, Mexico. In these estuaries, the ocean mixes with fresh water, and ecosystems are concentrated where petenes and pink flamingos proliferate. Crustaceans and mollusks abound in the sea. Despite its enormous marine wealth, there are no studies carried out on which halophilic microorganisms are present in these waters. In this work, the diversity and structure of the microbial community was investigated through a metagenomics approach and corroborated for sequencing of 16S rRNA genes. It was found that the phylum Fimicutes predominates with more than $50 \%$, in almost the same proportion of the class Bacilli and with almost $41 \%$ of relative abundance of the order Bacillales. The sequencing results showed that one of the samples presented a high percentage of similarity (99.75\%) using the Nucleotide BLAST program with a peculiar microorganism: Bacillus subtilis. This microorganism is one of the best characterized bacteria among the gram-positive ones. Our results demonstrate that B. subtilis can be an efficient source of proteases, lipases and cellulases, from halophilic microbial communities located in poorly explored areas.
\end{abstract}

Keywords: halophilic bacteria, Bacillus subtilis, proteases, lipases, cellulases.

\begin{abstract}
Resumo
Isla Arena está localizada na coordenada $20^{\circ} 70^{\prime} \mathrm{N}-90^{\circ} 45^{\prime} \mathrm{W}$, de Campeche, México. Nesses estuários, o oceano se mistura com a água doce e os ecossistemas se concentram onde proliferam petenos e flamingos rosa. Crustáceos e moluscos abundam no mar. Apesar de sua enorme riqueza marinha, não há estudos realizados sobre a presença de microrganismos halofílicos nessas águas. Neste trabalho, a diversidade e estrutura da comunidade microbiana foram investigadas através de uma abordagem metagenômica e corroboradas para o sequenciamento de genes 16S rRNA. Verificou-se que o filo Fimicutes predomina com mais de 50\%, quase na mesma proporção da classe Bacilli e com quase $41 \%$ de abundância relativa da ordem Bacillales. Os resultados do sequenciamento mostraram que uma das amostras apresentou alto percentual de similaridade (99,75\%) pelo programa Nucleotide BLAST com um microrganismo peculiar: Bacillus subtilis. Nossos resultados demonstram que B. subtilis pode ser uma fonte eficiente de proteases, lipases e celulases, provenientes de comunidades microbianas halofílicas localizadas em áreas pouco exploradas.
\end{abstract}

Palavras-chave: halofílico bactéria, Bacillus subtilis, proteases, lipases, celulases.

\section{Introduction}

Recently, with the use of next generation sequencing tools (metagenomics), it has been possible to discover a great taxonomic diversity of microbial species in common sites, but also in the most hostile sites (Alexios et al., 2018). A great deal of effort has been devoted to researching existing halophilic species and databases have been developed, such as the "HaloDom" (HaloDom, 2020). In this site, more than a thousand halophilic species are registered, (much more than in the HaloWeb (Dassarma et al., 2010), HaloBase (Ukani et al., 2011) and HProtDB (Sharma et al., 2014) databases combined). In this review it was found that $21.9 \%$ belong to Archaea, while $50.1 \%$ to Bacteria and $27.9 \%$ to Eukarya. This is an area showing rapid growth and this interest is reflected in the plethora of articles reporting new halophilic species each year, which is expected to increase (Albuquerque et al., 2016). Under this direction, we

*e-mail: luis.can.herrera.7@gmail.com

Received: November 29, 2020 - Accepted: April 2, 2021

This is an Open Access article distributed under the terms of the Creative Commons Attribution License, which permits unrestricted use, distribution, and reproduction in any medium, provided the original work is properly cited. 
found a niche of opportunity to explore a natural site with little disturbance located on the limits of the Los Petenes Biosphere Reserve (LPBR). LPBR is a protected natural area with a low level of human activity located in the southeast of Mexico. This site is basically a special saline swamp, which offers a high diversity of fauna and flora (VázquezLule et al., 2009). These biospheres are only found in the Yucatán Peninsula in Mexico, the Everglades in Florida and the Zapata Cienaga in Cuba (Torres Castro et al., 2009). Despite its high ecological importance, there are very few studies related to the state of the art of the microorganisms existing in this area. Vázquez-Lule et al. (2009), in 2009, published a list of algae and fungi present in LPBR and in surrounding areas, where they highlighted the presence of five groups of algae (Bryopsidophyceae, Chlorophyceae, Florideophyceae, Phaeophyceae and Rhodophyceae, with varied species) and five groups of fungi [Basidiomycota, Pteridophyta, Gymnospermae, Angiospermae (monocots) and Angiospermae (dicots)], the latter with a greater diversity of species. However, their report does not mention studies on bacteria. The only report about the exploration of bacteria in the LPBR zone and its limits (to our knowledge) is the one developed by Evangelista-Martínez (2014) in 2014. In his work, he isolated and characterized a total of 151 strains, finding a very high level of similarity with sequences related to different species of Streptomycetes; five of them exhibited a prominent antagonist activity for the biocontrol of pathogenic fungi. It should be noted that none of the species identified in the report was of the halophilic type.

In this sense, we present a work that consists fundamentally in identifying and characterizing a set of microbial communities, specifically halophilic, found at the limits of the LPBR, using massive sequencing and the amplification and sequencing of the 16S rRNA gene of halophilic microorganisms present in the Isla Arena Campeche swamp.

In this environment we found high-throughput sequencing targeting $16 \mathrm{~S}$ rRNA gene generated a total of 73,516 raw sequences and after processing the raw sequences, we obtained 29,653 sequences of good quality and 427 unique sequences used for classification, when phylum Fimicutes predominate, so that as Bacilli and Bacillales for class and order respectively. In order to determine the species, it was carried out a quantify and sequence the recombinant plasmid with any gene reported by the GenBank or the proteins to which the sequences could express, virtual platforms were used.

Ours results demonstrated that $B$. subtilis is an efficient source of enzymes such as proteases, lipases and cellulases, from microbial communities, specifically halophilic.

\section{Materials and Methods}

\subsection{Obtaining sediment and water samples}

Isla Arena is located in the coordinate $20^{\circ} 70^{\circ} \mathrm{N}$ - $90^{\circ} 45^{\prime} \mathrm{W}$, from Campeche, Mexico. The samples were obtained from different locations at the limits of the LPBR were selected, as shown in Figure 1. The coordinate of sample 1 (S1) was found in $20^{\circ} 56^{\prime} \mathrm{N}-90^{\circ} 41^{\prime} \mathrm{O}$, and the sample 2 (S2) in $20^{\circ} 61^{\prime} \mathrm{N}-90^{\circ} 42^{\prime} \mathrm{W}$, while the sample $3(\mathrm{~S} 3)$ in $20^{\circ} 67^{\circ} \mathrm{N}-90^{\circ} 42^{\prime} \mathrm{W}$. The collected samples consisted of a mixture of sediment and water, which was extracted using a plastic tube (PVC type, 2.5 in' diameter and 1.5 length). This tube was introduced into the collection area approximately $70 \mathrm{~cm}$ deep and the other end was covered with a rubber stopper, the tube was removed containing the sample, and collected use sterile Falcon tubes of $50 \mathrm{~mL}$, where the tubes were subsequently preserved freezing until further analysis. It should be noted that at the same time of the collection it was determined the temperature and $\mathrm{pH}$.

\subsection{Determination of salinity of the samples by the Mohr method}

The salinity of the collected samples was obtained by the determination of chlorides using the Mohr method (Sheen and Kahler, 1938). The sample consisted of a 1:10 dilution of water and sediment, respectively, a $0.1 \mathrm{M}$ silver nitrate $\left(\mathrm{AgNO}_{3}\right)$ solution was added, and $5 \%$ potassium

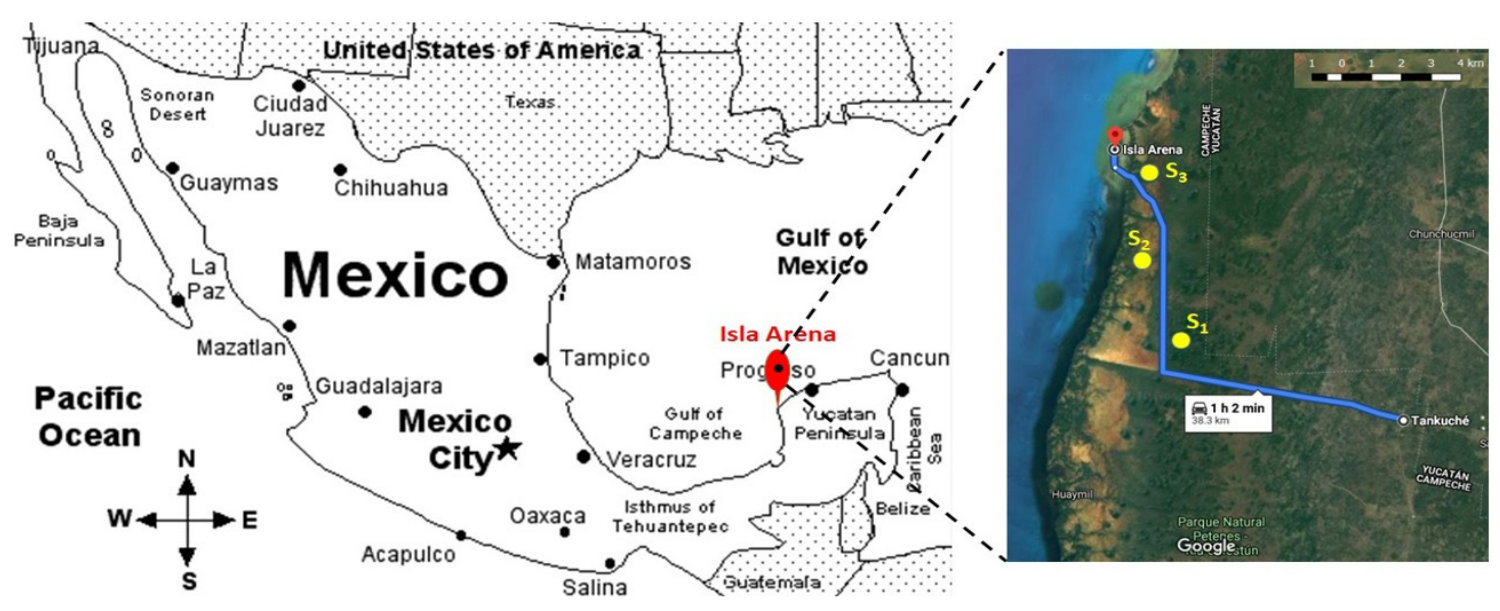

Figure 1. Sampling points (from 1 to 3 ) collected in the RBLP for metagenomics analysis. 
dichromate $\left(\mathrm{K}_{2} \mathrm{CrO}_{4}\right)$ was used as indicator. The results were reported as grams of chlorides corresponding to $\mathrm{NaCl}$, and were calculated using Equation 1.

$$
S \%=\left(1.8 \mathrm{ppmCl} / 10^{3}\right)+0.03 \text { (Equation 1) }
$$

\subsection{Liquid culture medium for bacterial enrichment}

The composition of the liquid culture medium used to enrich the populations of microorganisms present in the samples consisted of yeast extract (at a known percentage) and chitin colloidal, both with the purpose of to provide the bacteria with a source of carbon and nitrogen for their growth. The $\mathrm{pH}$ and salinity (as $\mathrm{NaCl}$ ) were adjusted to a proportion according to the conditions of the ecological niche of the samples (Carroad and Tom, 1978).

\subsection{DNA extraction}

Total DNA of the microorganisms present in the sediment was isolated using the PowerSoil kit (Qiagen, Valencia, CA, USA), according to the manufacturer's protocol. Prior to elution of the DNA, MB Spin Column was allowed to dry for $15 \mathrm{~min}$ at room temperature and subsequently eluted with $20 \mu \mathrm{L}$ of RNases-free water. The concentration and integrity of total DNA were determined using a Nanodrop 1000 (Thermo Scientific, USA) and 1.5\% agarose gel electrophoresis, respectively. The absorbance ratios A260/280 and A260/230 were found in an interval between 1.9 and 2.2 respectively, which are accepted purity values for sequencing.

\subsection{Metagenomics}

The DNA samples were processed with Targeted Metagenomic Sequencing by ZymoBIOMICS $®$ Service (Zymo Research, Irvine, CA).

\subsubsection{Targeted library preparation}

The DNA samples were prepared for targeted sequencing using custom targeted primer sets [Quick-16S ${ }^{\mathrm{TM}}$ Primer Set V3-V4 (Zymo Research, Irvine, CA)] with the Quick16S ${ }^{\mathrm{TM}}$ NGS Library Prep Kit (Zymo Research, Irvine, CA). The sequencing library was performed in real-time PCR to control cycles and therefore prevent PCR chimera formation. The final PCR products were pooled together based on equal molarity. The final pooled library was cleaned up with the Select-a-Size DNA Clean \& Concentrator ${ }^{\mathrm{TM}}$ (Zymo Research, Irvine, CA), then quantified with TapeStation ${ }^{\circledR}$ and Qubit®.

\subsubsection{Sequencing}

The final library was sequenced on Illumina ${ }^{\circledR} \mathrm{MiSeq}^{\mathrm{TM}}$ with a v3 reagent kit (600 cycles). The sequencing was performed with $>10 \%$ PhiX spike-in.

\subsubsection{Quality Controls (QC)}

A positive control was used for each targeted library preparation [ZymoBIOMICS ${ }^{\circledR}$ Microbial Community DNA Standard (Zymo Research, Irvine, CA)]. Negative controls (blank library preparation control) were included to assess the level of bioburden carried by the wet-lab process.

\subsubsection{Bioinformatics analysis}

Unique amplicon sequences were inferred from raw reads using the Dada2 pipeline (Callahan et al., 2016). Chimeric sequences were also removed with the Dada2 pipeline. Taxonomy assignment was performed using Uclust from Qiime v.1.9.1. and the 16S internal database of Zymo Research.

\subsection{Plasmid extraction and DNA sequencing}

For plasmid DNA extraction, the ZyppyTM Plasmid Miniprep kit from Zymo Research was used. Two $\mathrm{mL}$ of the medium was placed overnight in a $2 \mathrm{~mL}$ tube, and centrifuged for $1 \mathrm{~min}$ at $14,000 \mathrm{rpm}$ (twice). Subsequently, the pellet was re-suspended in $600 \mu \mathrm{L}$ of sterile water. Then $100 \mu \mathrm{L}$ of lysis buffer was added and left for 2-3 min mixing by inversion. Next, $350 \mu \mathrm{L}$ of neutralization buffer was added, again mixing by inversion. The supernatant was then centrifuged for 3 min at 14,000 rpm and the supernatant was placed in the kit columns. The columns were then centrifuged for $1 \mathrm{~min}$ at 14,000 rpm and the columns were placed in $1.5 \mathrm{~mL}$ Eppendorf tubes, $20 \mu \mathrm{L}$ of ultrapure water was added and allowed to stand in the columns for $5 \mathrm{~min}$. Finally, the tubes with the columns were centrifuged for $1 \mathrm{~min}$ at 14,000 rpm to recover the plasmid. These tubes with the samples were stored at $-20^{\circ} \mathrm{C}$ for preservation.

The recombinant plasmid was quantified by means of electrophoresis, according to the intensity of the bands presented by The Low DNA Mass ${ }^{\mathrm{TM}}$ Ladder (Invitrogen) and was sent for sequencing at the Davis Sequencing company (CA, USA).

\subsection{Identification of the sequences obtained}

For the interpretation of the sequencing result, the Chromas software was used to extract the sequence belonging to the samples, in order to identify the similarity of the sequence obtained with any gene reported by the GenBank or the proteins to which the sequences could be expressed, using virtual platforms such as BLAST (Basic Local Alignment Search Tool) from NCBI, Reverse Complement (Bioinformatics.Org., 2020) (Basic Local Alignment Search Tool) from NCBI, Reverse Complement (Bioinformatics.Org., 2020), BoxShade (The Swiss EMBnet node, 2020).

\subsection{Qualitative analysis of microorganisms}

The qualitative determination of microorganisms producing enzymatic activity was carried out by observing hydrolysis halos around the bacterial colonies, using Petri dishes with the solid culture medium, as reported by (Carroad and Tom, 1978). The culture medium was prepared by adjusting the $\mathrm{pH}$ and salinity for the values recorded in the habitats from which the samples were taken. To isolate microorganisms with potential enzymatic activity, an aliquot of $1 \mathrm{~mL}$ (from the sample) and $2 \%$ yeast extract and $1 \%$ colloidal chitin were taken and inoculated into 
$50 \mathrm{~mL}$ flasks in duplicate. It was incubated at $30{ }^{\circ} \mathrm{C}$ and $40{ }^{\circ} \mathrm{C}$, for 6-7 days, shaking at $175 \mathrm{rpm}$. Two enrichment phases were carried out, the isolation and selection of the producing microorganisms was carried out based on the observation in Petri dishes with solid medium of hydrolysis halos around the microbial colonies (Carroad and Tom, 1978). Tubes were prepared based on nutrient agar with the salinity and $\mathrm{pH}$ of the sample that was collected for 24 $h$. At the end of the incubation time, different growth tubes were taken and the cells were recovered using a sterile saline solution, with a $\mathrm{NaCl}$ concentration equal to that of the sample. Subsequently, the optical density (OD) was adjusted to the value corresponding to $1,000,000$ cells/ $\mathrm{mL}$, using a previously prepared standard curve.

\subsection{Determination of extracellular protein and enzymatic activities}

The extracellular protein content was determined using the Shimogaki et al. (1991) technique. With the aid of a previously prepared standard curve of bovine serum albumin. The cells were separated by centrifugation at $5,000 \mathrm{rpm}$ for $10 \mathrm{~min}$ at $4{ }^{\circ} \mathrm{C}$. For this technique it was required to previously prepare the reagents.

The proteolytic activity will be carried out using as substrate $2 \%$ casein in $0.2 \mathrm{M}$ phosphate buffer $\mathrm{pH} 7.0$ and $\mathrm{NaCl}$ at the concentration of the sample to be analyzed. This will be done by determining the tyrosine concentration using the Shimogaki technique, (Shimogaki et al., 1991).

Lipase activity of the cultures was screened on tributyrin nutrient agar plates containing $1 \%(\mathrm{v} / \mathrm{v})$ of tributyrin. Isolates that showed clear zones of tributyrin hydrolysis were identified as lipase producing bacteria.

The isolates were quantitatively tested for cellulase production by means of $1 \%$ Carboxymethyl cellulose in basal salt medium using plate assay procedure, according to Hankin and Anagnostakis (1977), method (1977). Adding $0.1 \%$ Congo red reagent and counterstaining with $1 \mathrm{M} \mathrm{NaCl}$ for 20 min resulted in cellulose hydrolysis that formed opaque zone surrounding the colony.

\section{Results}

\subsection{Isolation of halophiles bacteria}

Halophiles bacterial have been identified as a potential source of industrially useful enzymes endowed with exceptional stabilities. This stability of halophilic microorganisms allows, among other applications, the capacity for bioremediation (Ramirez et al., 2018).

This work was undertaken to screen stable enzymes from halophiles occurring in saline habitats from Isla Arena, Campeche, Mexico. It should be noted that two of the three samples did not contain a sufficient concentration of DNA, so their identification was not possible, as shown in Table 1.

\subsection{Read processed and relative abundance}

This study area included 3 sites with different sediment type. The results of high-throughput sequencing targeting 16S rRNA gene generated a total of 73,516 raw sequences (see Table 1 ). After processing the raw sequences, we obtained 29,653 sequences of good quality and 427 unique sequences (OTUs) used for classification. In this environment, more than 73 thousand raw sequences were analyzed.

As it can be observed in Figure 2, after metagenomics analyses in DNA purified from the samples of soil, the relative abundance of a wide diversity of bacterial species grouped in Phylum, Class and Order, however only the names of five most abundant of each one are shows.

The phylum Fimicutes predominates with more than 50.5\%, followed by Proteobacter (18.7\%), Chloroflexi (8.9\%), Gemmatimonadetes (5.4\%) and Actinobacter (4.3\%).

Continuing with the class classification, it was found that Bacilli record a $50.2 \%$, followed by Anaerolineae (7.6\%), Deltaproteobacter (6.2\%), Alphaproteobacter (5.7\%) and Gemmatimonadetes (5.4\%). Finally, with almost $41.5 \%$ of relative abundance the order of Bacillales, followed by Lactobacillales (8.7\%), Anaerolineales (7.6\%), Gemmatimonadetes (5\%) and Mariprofundales (3.8\%) as can be seen in the Figure 2. To above shown that the soil of the LPBR is mainly composed of the phylum Firmicutes (Figure 2b).

Given that the objective of this work was to investigate the diversity and structure of the microbial community by metagenomics analysis and to corroborate it by sequencing the $16 \mathrm{~S}$ rRNA genes, we proceeded to carry out the corresponding quantification and sequencing of the recombinant plasmid by electrophoresis.

\subsection{Sequences obtained.}

The sample proved to be of good quality to be sequenced by reverse orientation of plasmid LSC-29 (see Figure 3a). Therefore, this sequence was analyzed in different computer programs, such as NCB, BLAST, BOXSHADE etc. For the particular identification of any microorganism

Table 1. Quantification of DNA extraction with the commercial DNeasy PowerSoil Kit (100), and the number of reads processed of samples.

\begin{tabular}{cccccccccc}
\hline Samples & $\begin{array}{c}\text { DNA } \\
\text { concentration } \\
(\mathbf{n g} / \mu \boldsymbol{L})\end{array}$ & A260 & A280 & $\mathbf{2 6 0 / 2 8 0}$ & $\mathbf{2 6 0 / 2 3 0}$ & $\boldsymbol{R S}$ & SGQ & $\begin{array}{c}\text { Chimera } \\
\text { free seqS }\end{array}$ & $\begin{array}{c}\text { Unique } \\
\text { seqs }\end{array}$ \\
\hline S1 & N/A & -- & -- & -- & -- & -- & -- & -- & -- \\
S2 & 55.6 & 1.112 & 0.62 & 1.8 & 1.1 & 73,016 & 29,653 & 30,934 & 427 \\
S3 & N/A & -- & -- & -- & -- & -- & -- & -- & -- \\
\hline
\end{tabular}

DNA: A good- quality DNA will have an A260/A280 ratio of 1.7-2.0. A reading of 1.6 does not render the DNA unsuitable for any application, due lower ratio indicate more contaminants are present; RS: raw sequences; SGQ: sequences of good quality, N/A: Not Applied, because the samples did not contain a sufficient concentration of DNA, so their identification was not possible. 
a)

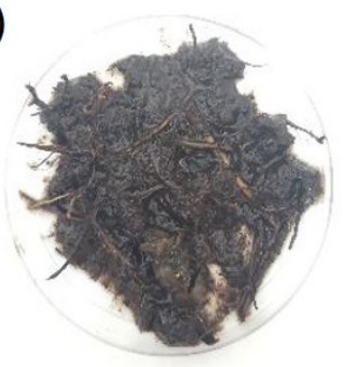

c)

- C_Bacilli

- C__Anaerolineae

- C_Deltaproteobacteria

- c_Alphaproteobacteria

- C__Gemmatimonadetes

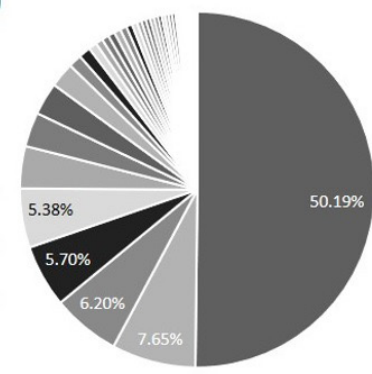

b)

- p_Firmicutes

- p__Proteobacteria

- p_Chloroflexi

- p__Gemmatimonadetes

p_Actinobacteria

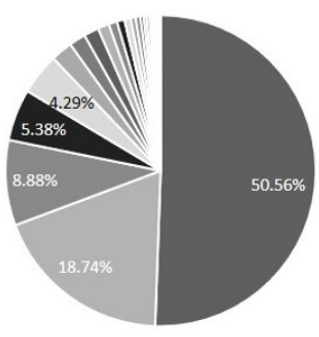

d)

- o_Bacillales

- o_LLactobacillales

- o__Anaerolineales

- c__Gemmatimonadetes

o__Mariprofundales

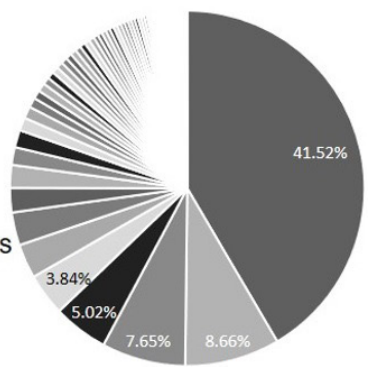

Figure 2. Relative abundance of the bacterial community in sediments. (a) sample, (b) phylum, (c) class, and (d) order.

$>$ LSC-29+M13R

a) GGGGRTCCTCTATACGACTCACTATAGGGAGCTTGCATGCAGGCCTCTGCAGTCGACGGG CCCGGGATCCGATTCGGGAACGTATTCACCGCGGCATGCTGATCCGCGATTACTAGCGAT TCCAGCTTCACGCAGTCGAGTIGCAGACTGCGATCCGAACTGAGAACAGATTTGGGGAT TGGCTTAACCTCGCGGTाTCGCTGCCCTTTGTTCTGTCCATTGTAGCACGTGTGTAGCCC AGGTCATAAGGGGCATGATGATTTGACGTCATCCCCACCTTCCTCCGGTTTGTCACCGGC AGTCACCTTAGGGTGCCCAACTGAATGCTGGCAACTAAGATCAAGGGTTGCGCTCGTTGC GGGACTTAACCCAACATCTCACGACACGAGCTGACGACAACCATGCACCACCTGTCACTC TGCCCCCGAAGGGGACGTCCTATCTCTAGGATTGTCAGAGGATGTCAAGACCTGGTAAGG ПTTTCGCGTIGCTTCGAATTAAACCACATGCTCCACCGCTTGTACGGGCCCCCGTCAAT TCCTTGAGTITCAGTCTTGCGACCGTACTCCCCAGGCGGAGTGCTTAATGCGTTAGCTG CAGCACTAAGGGGCGGAAACCCCCTAACACTTAGCACTCATCGTTAACGGCGTGGACTAC CAGGGTATCTAATCCTGTTCGCTCCCCACGCTTTCGCTCCTCAGCGTCAGTTACAGACCA GAGAGTCGCCTTCGCCACTGGTGTTCCTCCACATCTCTACGCATTTCACCGCTACACGTG GAATTCCACTCTCCTCTTCTGCACTCAAGTTCCCCAGTTTCCAATGACCCTCCCCGGTTG AGCCGGGGGCTTICACATCAGACTTAAGAAAC

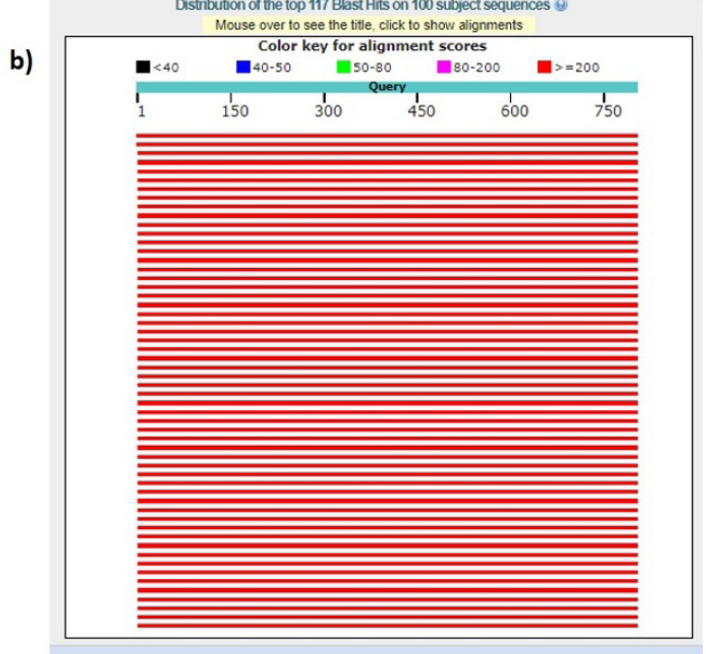

Distribution of the top 117 Blast Hits on 100 subject sequences Mouse over to see the tifle, click to show alignments
Color key for alignment scores

$\phi$

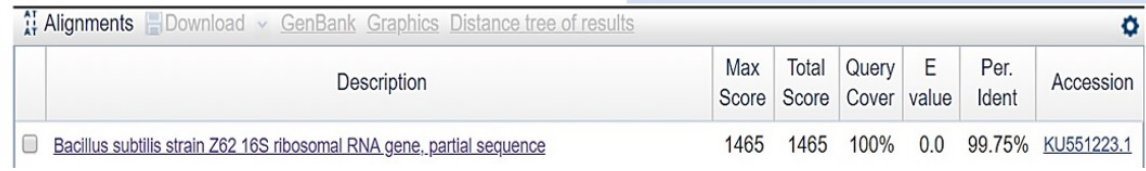

Figure 3. (a) Sample sequence> LSC-29+M13R, visualized through the Chromas program. The sequence shaded in gray belongs to the vector according to BLAST Results Vecscreen corresponding to 73 bases. Remaining bases correspond to the actual sequence of the microorganism; (b) Result of the relationship of the sequence obtained in the results of the BLAST computer program (Basic Local Alignment Search Tool). With a percentage of $99.75 \%$ it was Bacillus subtilis strain Z62 16 S ribosomal RNA gene.

where the results showed that the sequence obtained presented $99.75 \%$ similarity with the $16 \mathrm{~S}$ rRNA gene of Bacillus subtilis (see Figure 3b). The sequence was observed in the Cromas program, while the sequencing parentage result was determined in the BLAST program. The sequence corresponding to this parentage is Bacillus subtilis strain Z62 16S ribosomal RNA gene, partial sequence GenBank: KU551223.1. To corroborate the alignment of the sequence of interest, these were entered into the Multiple Sequence Alignment program, where these paired bases were observed (not include the figure).

B. subtilis is especially preferred for protease, cellulase, lipase, pullulanase and xylanase enzymes, the production of which represents about $60 \%$ of the commercially available industrial enzymes (Morikawa, 2006; Priest, 1977). 


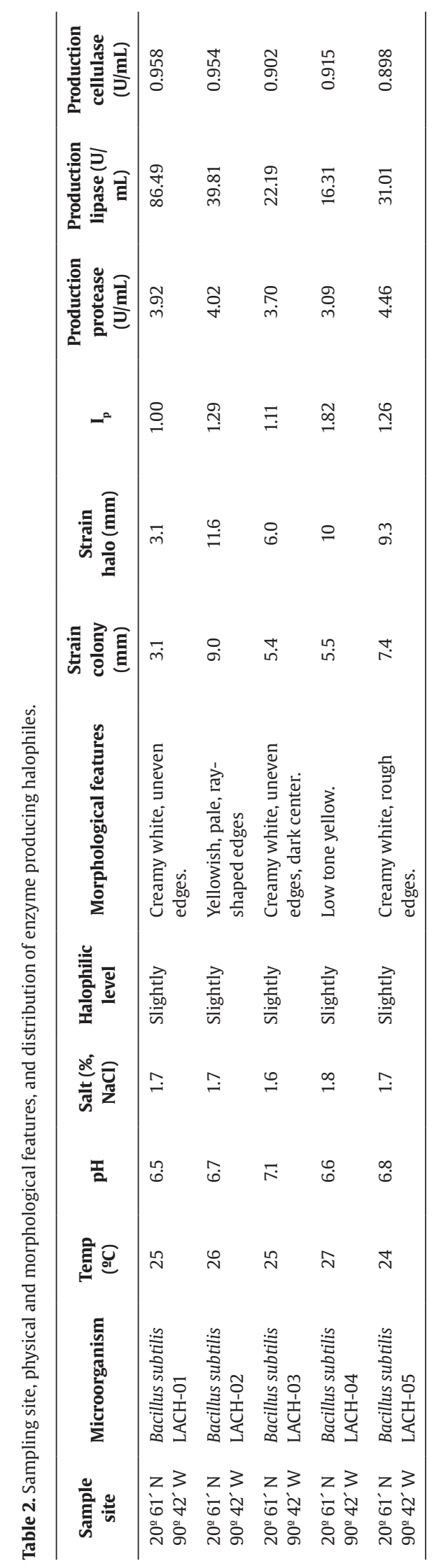


In this sense, based on the results obtained, we decided to know the capacity of this microorganism isolated from a pristine area of Campeche, Mexico, to produce specifically proteolytic, lipolytic and cellulolytic enzymatic activity.

From the identification of the genus $B$. subtilis, five repetitions were carried out to determine the capacity to produce enzymatic activities of this strain and the results are presented below (Seong et al., 2018).

\section{Discussions}

\subsection{Relative abundance of bacterial species in the samples}

The metagenomics analyzes provided relevant information about the relative abundance consisting of a great diversity of bacterial species, where the phylum Firmicutes predominated with more than $50 \%$. Members of the phylum Firmicutes are abundant in soil and aquatic environments where they are involved in the decomposition and recycling of organic matter (Baik et al., 2008). Also, several genera are normal flora of the mammalian intestine, humans, animals, and plants (Nguyen and Götz, 2016). For example, Silva et al., found recently aspartic proteases of industrial and biotechnological interest from the stomach of a fish (crevalle jack fish, Caranx hippos) (Silva et al., 2022). Other members of Firmicutes are industrially valuable for the production of antibiotics, enzymes, and dairy products (Kwak et al., 2013). Furthermore, specifically the order Bacillales (50.2\% of relative abundance, found in this work) has been shown to have various commercial applications that include cleaning agents in detergents, in starch modification, and other chemicals (Stein, 2005). This order it has been found to have high antifungal activity, playing an important role in the infection cycle of plant pathogens too (Oliveira et al., 2021).

\subsection{Screening of halophiles bacteria enzyme producers}

In this study identified slightly halophilic bacteria showing at concentration of $1.6-1.8 \% \mathrm{NaCl}(\mathrm{w} / \mathrm{v}), \mathrm{pH}$ values $6.5-7.1$ and temperature values $24-27^{\circ} \mathrm{C}$. So that, microorganisms displaying physiological properties such as those mentioned they are stable and under normal environmental conditions could present attractive enzymatic activities.

Protease, lipase and cellulase were chosen for the study, considering their high industrial usage. Maximum activity proteolytic was produced by sample LACH-05, while lipase and cellulase production level were maximum for $\mathrm{LACH}-$ 01 sample (see Table 2 ).

Bacillus proteases have many remarkable characteristics for diverse industrial applications, such as broad $\mathrm{pH}$ (5-9) and temperature activity $\left(20-45^{\circ} \mathrm{C}\right)$ stability range, alkaline and toxic compounds tolerance, even oxidants and surfactants (Contesini et al., 2018). Also, the multiple applications presently using alkaline proteases are reported by Kamal et al. (2016). Bacterial keratinases are serinetype proteases that exhibit optimal activity at a $\mathrm{pH}$ of 6-9 and a temperature range of $30-50^{\circ} \mathrm{C}$ (Tamreihao et al., 2019). In our work, this specie showed a considerable production protease among 3.09-4.46 U/mL, with an $I_{p}$ between 1.00-1.82.

In previous studies, diverse types of genera have been reported for producing the cellulase enzyme including B. subtilis (Kim et al., 2009). Siu-Rodas et al. (2018) reported that the enzymatic extracts obtained from composting with coffee residues of three strains showed exocellulase and endocellulase maximum activity of 0.254 and 0.519 $\mathrm{U} / \mathrm{mL}$, respectively. They found that, the activity of these enzymes was maintained even in acid $\mathrm{pH}$ (4.8) and basic (9.3) and at temperatures of up to $60^{\circ} \mathrm{C}$. They concluded enzymatic activities observed in their study are within the highest reported for cellulose produced by bacteria of the genus Bacillus. In our study, it found a production cellulose major, among 0.898-0.958 U/mL, for a minor temperature between $24-27^{\circ} \mathrm{C}$ and at almost neutral pH 6.5-7.1.

On the other hand, due to its stability, the lipases have immense industrial importance.

The most useful lipase producing genus employed in the industry is Bacillus (Mazhar et al., 2017). They are gram-positive endospore formers that produce a wide variety of enzymes and are considered strong extra cellular lipase producer. They demonstrate the ability to grow in various ranges of temperature, $\mathrm{pH}$, and salt concentration. Mazhar et al. (2017), used 16S rRNA gene sequencing to identify the genus of the bacterial strain (B. subtilis PCSIRNL-39), and found that the maximum lipolytic activity $(55.17 \mathrm{U} / \mathrm{mL})$ occurred at a temperature of $45^{\circ} \mathrm{C}$, which is in agreement with the result of Ma et al. (2006) for the strain of B. subtilis IFFI 10210. Our result shows a higher lipase production between 16.31-86.49 U/mL, but at a lower temperature $\left(24-27^{\circ} \mathrm{C}\right)$.

Finally, the identification as a first step from metagenomics the phylum, class, and order of a strain from pristine area of Campeche, Mexico was carried out. We found more than 73,000 raw sequences, and 427 unique sequences from the phylum Fimicutes predominates and the Bacilli and Bacillales for class and order respectively. In order to identify the strain specifically developed a sequence of the 16S rRNA gene, where found that has a similarity of 99.75 with the Bacillus subtilis reported by the GenBank (using BLAST of NCBI). In this work, the B. subtilis as an efficient source of industrial enzymes such as proteases, lipases and cellulases, from halophiles microorganisms it was demonstrated.

\section{Acknowledgements}

This work was funded by Tecnológico Nacional de México (TecNM, México). L. A. Can-Herrera acknowledges to TecNM for the financial of project with number 531.18PD [project key: r129k1 (4212)].

\section{References}

ALBUQUERQUE, L., KOWALEWICZ-KULBAT, M., DRZEWIECKA, D., STĄCZEK, P., D'AURIA, G., ROSSELLÓ-MÓRA, R. and DA COSTA, M.S., 2016. Halorhabdus rudnickae sp. nov., a halophilic Archaeon isolated from a salt mine borehole in Poland. Systematic and 
Applied Microbiology, vol. 39, no. 2, pp. 100-105. http://dx.doi. org/10.1016/j.syapm.2015.12.004. PMid:26749115.

ALEXIOS, L., KAPPAS, I. and ABATZOPOULOS, T.J., 2018. HaloDom: a new database of halophiles across all life domains. Journal of Biological Research (Thessaloniki), vol. 25, pp. 2. http://dx.doi. org/10.1186/s40709-017-0072-0.

BAIK, K.S., PARK, S.C., KIM, E.M., BAE, K.S., ANN, J.-H., KA, J.-O., CHUN, J. and SEONG, C.N., 2008. Diversity of bacterial community in freshwater of Woopo wetland. Journal of Microbiology (Seoul, Korea), vol. 46, no. 6, pp. 647-655. http://dx.doi.org/10.1007/ s12275-008-0135-x. PMid:19107393.

BIOINFORMATICS.ORG., 2020 [viewed 20 November 2020]. Reverse complement of BLAST [online]. Available from: http://www. bioinformatics.org/sms/rev_comp.html

CALLAHAN, B.J., MCMURDIE, P.J., ROSEN, M.J., HAN, A.W., JOHNSON, A.J. and HOLMES, S.P., 2016. DADA2: high resolution sample inference from Illumina amplicon data. Nature Methods, vol. 13, no. 7, pp. 581-583. http://dx.doi.org/10.1038/nmeth.3869. PMid:27214047.

CARROAD, P.A. and TOM, R.A., 1978. Bioconversion of shellfish chitin wastes: process conception and selection of microorganisms. Journal of Food Science, vol. 43, no. 4, pp. 1158-1161. http:// dx.doi.org/10.1111/j.1365-2621.1978.tb15259.x.

CONTESINI, F.J., MELO, R.R. and SATO, H.H., 2018. An overview of Bacillus proteases: from production to application. Critical Reviews in Biotechnology, vol. 38, no. 3, pp. 321-334. http:// dx.doi.org/10.1080/07388551.2017.1354354. PMid:28789570.

DASSARMA, S.L., CAPES, M.D., DASSARMA, P. and DASSARMA, S. 2010. HaloWeb: the haloarchaeal genomes database. Saline Systems, vol. 6, pp. 12. PMid:21192823.

EVANGELISTA-MARTÍNEZ, Z., 2014. Isolation and characterization of soil Streptomyces species as potential biological control agents against fungal plant pathogens. World Journal of Microbiology E Biotechnology, vol. 30, no. 5, pp. 1639-1647. http://dx.doi. org/10.1007/s11274-013-1568-x. PMid:24310522.

HANKIN, L. and ANAGNOSTAKIS, S.L., 1977. Solid media containing carboxymethylcellulose to detect $\mathrm{Cx}$ cellulase activity of microorganisms. Journal of General Microbiology, vol. 98, no. 1, pp. 109-115. PMid:401863.

HALODOM, 2020 [viewed 20 November 2020]. [online]. Available from: http://www.halodom.bio.auth.gr

KAMAL, S., REHMAN, S. and IQBAL, H.M., 2016. Biotechnological valorization of proteases: from hyperproduction to industrial exploitation-a review. Environmental Progress \& Sustainable Energy, vol. 36, no. 2, pp. 511-522. http://dx.doi.org/10.1002/ ep.12447.

KIM, B.K., LEE, B.H., LEE, Y.J., JIN, I.H., CHUNG, C.H. and LEE, J.W., 2009. Purification and characterization of carboxymethylcellulase isolated from a marine bacterium, Bacillus subtilis subsp. subtilis A-53. Enzyme and Microbial Technology, vol. 44, no. 6-7, pp. 411-416. http://dx.doi.org/10.1016/j.enzmictec.2009.02.005.

KWAK, M.K., LIU, R., KWON, J.O., KIM, M.K., KIM, A.H.J. and KANG, S.O., 2013. Cyclic dipeptides from lactic acid bacteria inhibit proliferation of the Influenza A virus. Journal of Microbiology (Seoul, Korea), vol. 51, no. 6, pp. 836-843. http://dx.doi. org/10.1007/s12275-013-3521-y. PMid:24385362.

MA, J., ZHANG, Z., WANG, B., KONG, X., WANG, Y., CAO, S. and FENG, Y., 2006. Over expression and characterization of a lipase from Bacillus subtilis. Protein Expression and Purification, vol. 45, no. 1, pp. 22-29. http://dx.doi.org/10.1016/j.pep.2005.06.004. PMid:16039141.

MAZHAR, H., ABBAS, N., ALI, S., SOHAIL, A., HUSSAIN, Z. and ALI, S.S., 2017. Optimized production of lipase from Bacillus subtilis
PCSIRNL-39. African Journal of Biotechnology, vol. 16, no. 19, pp. 1106-1115. http://dx.doi.org/10.5897/AJB2017.15924.

MORIKAWA, M., 2006. Beneficial biofilm formation by industrial bacteria Bacillus subtilis and related species. Journal of Bioscience and Bioengineering, vol. 101, no. 1, pp. 1-8. http:// dx.doi.org/10.1263/jbb.101.1. PMid:16503283.

NGUYEN, M.T. and GÖTZ, F., 2016. Lipoproteins of Gram-positive bacteria: key players in the immune response and virulence. Microbiology and Molecular Biology Reviews, vol. 80, no. 3, pp. 891-903. http://dx.doi.org/10.1128/MMBR.00028-16. PMid:27512100.

OLIVEIRA, J.C., SALES, J.F., RUBIO-NETO, A., SILVA, C.F., SOARES, M.A. and SILVA, F.G., 2021. Biological control in the germination of seeds from two species native of the Cerrado region. Brazilian Journal of Biology $=$ Revista Brasileira de Biologia, vol. 81, no. 1, pp. 105-113. http://dx.doi.org/10.1590/1519-6984.222279. PMid:32159616.

PRIEST, F.G., 1977. Extracellular enzyme synthesis in the genus Bacillus. Bacteriological Reviews, vol. 41, no. 3, pp. 711-753. http://dx.doi.org/10.1128/br.41.3.711-753.1977. PMid:334155.

RAMÍREZ, M.E., VÉLEZ, Y.H., RENDÓN, L. and ALZATE, E., 2018. Potential of microalgae in the bioremediation of water with chloride content. Brazilian Journal of Biology = Revista Brasileira de Biologia, vol. 78, no. 3, pp. 472-476. http://dx.doi. org/10.1590/1519-6984.169372. PMid:29069164.

SEONG, C.N., KANG, J.W., LEE, J.H., SEO, S.Y., WOO, J.J., PARK, C., BAE, K.S., and KIM, M.S., 2018. Taxonomic hierarchy of the phylum Firmicutes and novel Firmicutes species originated from various environments in Korea. Journal of Microbiology, vol. 56, no. 1, p. 1-10. http://dx.doi.org/10.1007/s12275-0187318-X. PMID: 29299839.

SHARMA, N., FAROOQI, M.S., CHATURVEDI, K.K., LAL, S.B., GROVER, M., RAI, A., and PANDEY, P., 2014. The Halophile protein database. Database (Oxford), vol. 2014, bau114. http://dx.doi.org/10.1093/ database/bau114.

SHEEN, R.T. and KAHLER, H.L., 1938. Effects of ions on mohr method for chloride determination. Industrial \& Engineering Chemistry. Analytical Edition, vol. 10, no. 11, pp. 628-629. http://dx.doi. org/10.1021/ac50127a004.

SHIMOGAKI, H., TAKEUCHI, K., NISHINO, T., OHDERA, M., KUDO, T., OHBA, K., IWAMA, M. and TRIE, M., 1991. Purification and properties of a novel surface active agent and alkaline-resistant protease from Bacillus sp. Agricultural and Biological Chemistry, vol. 55, no. 9, pp. 2251-2258. http://dx.doi.org/10.1271/ bbb1961.55.2251. PMid:1368737.

SILVA, J.A.F., SILVA, M.K.S., SILVA, T.A., COSTA, L.D.A., LEAL, M.L.E., BEZERRA, R.S., COSTA, H.M.S. and FREITAS-JÚNIOR, A.C.V., 2022. Obtainment and characterization of digestive aspartic proteases from the fish Caranx hippos (Linnaeus, 1766). Brazilian Journal of Biology = Revista Brasileira de Biologia, vol. 82, pp. e234500. http://dx.doi.org/10.1590/1519-6984.234500.

SIU-RODAS, Y., CALIXTO-ROMO, M.A., GUILLÉN-NAVARRO, K., SÁNCHEZ, J.E.,ZAMORA-BRISENO,J.A. and AMAYA-DELGADO, L., 2018. Bacillus subtilis with endocellulase and exocellulase activities isolated in the thermophilic phase from composting with coffee residues. Revista Argentina de Microbiologia, vol. 50, no. 3, pp. 234-243. http://dx.doi.org/10.1016/j.ram.2017.08.005. PMid:29289440.

STEIN, T., 2005. Bacillus subtilis antibiotics: structures, syntheses and specific functions. Molecular Microbiology, vol. 56, no. 4, pp. 845-857. http://dx.doi.org/10.1111/j.1365-2958.2005.04587.x. PMid:15853875.

TAMREIHAO, K., MUKHERJEE, S., KHUNJAMAYUM, R., DEVI, L.J., ASEM, R.S. and NINGTHOUJAM, D.S., 2019. Feather 
degradation by keratinolytic bacteria and biofertilizing potential for sustainable agricultural production. Journal of Basic Microbiology, vol. 59, no. 1, pp.4-13. http://dx.doi.org/10.1002/ jobm.201800434. PMid:30353928.

THE SWISS EMBNET NODE. 2020 [viewed 20 November 2020]. Plataform Boxshade [online]. Available from: https://embnet. vital-it.ch/software/BOX_form.html

TORRES CASTRO, I.L., VEGA CENDEJAS, M.E., SCHMITTER SOTO, J.J., PALACIO APONTE, G. and RODILES HERNÁNDEZ, R., 2009. Ichthyofauna of karstic wetlands under anthropic impact: the "petenes" of Campeche, Mexico. Revista de Biología Tropical, vol. 57, no. 1-2, pp. 141-157. PMid:19637696.
UKANI, H., PUROHIT, M.K., GEORRGE, J.J., PAUL, S. and SINGH, S.P., 2011. HaloBase: development of database system for halophilic bacteria and archaea with respect to proteomics, genomics \& other molecular traits. Journal of Scientific and Industrial Research, vol. 70, no. 11, pp. 976-981. http://dx.doi. org/10.5281/zenodo.4398512.

VÁZQUEZ-LULE, A.D., REYES-CASTELLANOS, J.E. and AGRAZHERNÁNDEZ, C., 2009. Caracterización del sitio de manglar Peténes. In: COMISIÓN NACIONAL PARA EL CONOCIMIENTO Y USO DE LA BIODIVERSIDAD - CONABIO. Sitios de manglar con relevancia biológica y con necesidades de rehabilitación ecológica. México, D.F.: CONABIO. 